\title{
Building maintenance management in Malaysia
}

Received (in revised form): 14th August, 2008

\section{Olanrewaju Abdul Lateef}

holds a Master's of Science in Built Environment from the International Islamic University Malaysia. He has six years' working experience as a quantity surveyor in Nigeria. He is currently with the Procurement and System Research Delivery Group at the International Islamic University Malaysia.

Correspondence: Olanrewaju Abdul Lateef, Procurement and System Research Delivery Group, Kulliyah of Architecture and Environmental Design, International Islamic University Malaysia, Kuala Lumpur 531000, Malaysia; Tel: +601 638 89605 ; Fax: +60161965239; E-mail: olanrewaju20002000@yahoo.com

\begin{abstract}
Investment in building maintenance is huge all over the world. In most countries, it represents almost 50 per cent of the total turnover of the construction industry. The value of buildings depends on the quality of the maintenance invested in them. Maintenance management involves obtaining maximum benefit from the investment made on the maintenance activities. Maintenance in buildings in Malaysia is on the increase regardless of size, type, location, and ownership. The current maintenance management procedures in Malaysia are, however, condition and reactive based. The weaknesses in the current procedures are the primary problems because they do not explicitly link maintenance needs with building performance with respect to the building users. The building users measure the performance of a building with various criteria. The condition of a building is just one of those criteria. This research establishes the need for a building maintenance management system that is based on the concept of value in the effort to lead towards the optimisation of building maintenance programmes. Maintenance management that is value based allows users to be proactively put at the centre of maintenance management during decisionmaking processes and takes into consideration both the objective and subjective requirements of users.
\end{abstract}

Journal of Building Appraisal (2009) 4, 207-214. doi:10.1057/jba.2008.27

\section{Keywords:}

building, maintenance, procedures, Malaysia, management

\section{INTRODUCTION}

The purpose of this paper is to look at the maintenance and maintenance management of buildings in Malaysia. This research aims to improve the value of buildings through a proactive maintenance management system that is based on the concept of value.

Although this paper serves as an overview of ongoing research, it intends to establish the rationalisation for further research towards the development of a value-based building maintenance management system to improve the value of buildings in Malaysia. In Malaysia, building maintenance is conditionally driven and is usually carried out only when there is money, even if the needs are obvious until such a situation when the building becomes unattractive or even unsuitable for its users and the populace. As such, building maintenance is not regarded as part of the production processes, that is, not as a factor of production. There is no doubt that the government is consistently increasing its 
allocation to the maintenance sector, but the allocation is grossly inadequate to meet the ever-growing demand for the maintenance backlog. Therefore, there is a need for a broad and systematic value-based procedure related to building maintenance that puts the building users at the centre of maintenance planning, control, and implementation. A maintenance management system that is value based provides a clear definition of the goals of the maintenance programmes and policies as well as establishing the problems the maintenance is expected to solve. This paper starts with a background to the research, then an assessment of the existing maintenance procedures and, finally, a conclusion. The background identifies the size and nature of building maintenance in Malaysia. The assessment analysis of the existing procedures centres on the procedures that are used to manage the maintenance of buildings in Malaysia.

\section{BACKGROUND: BUILDINGS MAINTENANCE MANAGEMENT}

In the last three decades, Malaysia has witnessed immense growth in many sectors of the economy, not least in the construction industry. Naturally, in tandem with the increase in the contribution of the construction industry to the GDP, there is also an expansive increase in the contribution of the real estate subsector (Hishamuddin and Buang, 2006). In terms of value, the contribution of the finance, insurance, real estate, and business and services sectors increased from US\$7,661 m in 1999 to US\$12,137m in 2005 (Department of Statistics, Malaysia, 2006). The sectors in the real estate industry are the housing and infrastructural facilities. The economy of Malaysia has, since independence, been planned on the basis of five-year strategic plans. During each of the Malaysian plans, the real estate sector has featured prominently (Tan, 2006) both in terms of value and policy implementation. In association with this is the expansive and consistent increase in property incomes. For instance, the contribution of property income was US $\$ 1,762 \mathrm{~m}$ in 1994, while it had increased to US $\$ 3,352 \mathrm{~m}$ by 2003 (United Nations, 2006). The total outstanding loans to the property sector as of 2005 were $73 \mathrm{bn}$ (Central Bank of Malaysia, 2006). In 2005, the growth in the finance, insurance, real estate, and business service subsectors was sustained at 5.4 per cent (Central Bank of Malaysia, 2006).

In terms of housing stocks, the federal development expenditure has increased by 24.6 per cent from 1999 to 2006. For instance, in financial value, the development expenditure increased from US\$332m in 1999 to US\$413m in 2006 (The Europa World Year Book, 2004, 2005, 2006, 2007). In terms of numbers, there were 3.59 million residential units in Malaysia (Central Bank of Malaysia, 2006). In addition, under the Ninth Malaysian Plan, it was estimated that 709,400 housing units will be built or constructed (Government of Malaysia, 2006). In tandem with this, with the increase in supply of buildings, the amount invested in building maintenance is also increasing (Government of Malaysia, 2006). For instance, there was an increase of 14.3 per cent in the number of maintenance contracts awarded from 2001 to 2002 (CIDB, 2003). In 2001, 238 maintenance contracts were awarded, while the number increased to 272 in 2002. In terms of value, investment in maintenance was about US $\$ 613,308,787$ (CIDB, 2003). This represents about 6 per cent of the total construction contract awarded in the period. Under the Ninth Malaysian Plan (2000-2010), the government has allocated the sum of US\$330m for upgrading, renovating, and maintaining various facilities as part of the development budget (Government of Malaysia, 2006; Mohd Sidek, 2007). This represents 0.5 per cent of the total development budget. This also represents a 150 per cent increase in allocation to the sector as compared to the 0.2 allocation under the Eighth Plan (2001-2005). Fourteen thousand dilapidated houses will be rehabilitated in the rural areas under the Ninth 
Malaysian Plan (Government of Malaysia, 2006). Therefore, building maintenance is becoming a major activity because enormous resources are being committed as the government is recognising the need for building maintenance. This will probably be the case in the years ahead, as buildings require maintenance to be able to perform efficiently. In fact, it will be more particularly so in developing countries like Malaysia where there is no proper maintenance management system for buildings. Buildings are assets, the value of which changes in accordance with the quality of the maintenance invested in them. If proper maintenance is invested in a building, the value will improve and vice versa. Further, the needs for maintenance works will be expected to increase, since it is not always cost-effective to demolish, reconstruct, or rebuild new facilities to replace existing ones.

Despite the government's commitment towards building maintenance, buildings have not been effectively maintained. For instance, Ahmad et al. (2006) opined that in Malaysia, maintenance problems in buildings are common regardless of the size and owners of the buildings. Ahmad (2006) conducted a case study on 16 large properties (covering $381,804.55 \mathrm{~m}^{2}$ net floor area) owned by Pertubuhan Keselamatan Sosial (PERKESO), a government subsidiary. On the basis of his findings, he concluded that the buildings lacked adequate maintenance despite the enormous resources committed to the maintenance activities. Based on case studies conducted in Kuala Lumpur to assess the conditions of buildings, Kayan $(2006 a$, b) noted that many buildings faced maintenance problems that need urgent attention in order to preserve them from further deterioration and decay. Syamilah (2006) investigated the buildings of more than 50 schools in Petaling Jaya, and concluded that there was a lack of adequate maintenance. It is has been reported that pipe leakages have brought the operations of the just completed US\$61,330,879 Immigration Headquarters to a halt (The Star, 2007, p. N4). Forty assembly men and women scrambled for safety as a cornice in the main lobby crashed at the State Legislative Assembly building (New Straits Times, 2008, p. 12; The Star, 2008a, b, p. N14).

The New Straits Times (2007) reports the maintenance problems in the building occupying the Ministry of Entrepreneur and Cooperatives Development. The poor condition of the ceiling panels in the newly completed US\$82,796,686 Kuala Lumpur Court Complex (the second biggest court in the world) in Jalan Duta has also become a source of serious concern to the government, users, and the public (New Straits Times, 2007). Zuhairuse et al. (n.d.) carried out a case study on multi-ownership housing in the Klang Valley and inferred that the quality of maintenance invested in the buildings is not effective. A major problem faced by property developers in Malaysia was discovered to be poor collection of maintenance fees, the major reason being the dissatisfaction on the part of users with the condition of their buildings (Noraziah, 2006). The deplorable conditions of open market areas are increasingly becoming unsightly and disturbing, as rodents can be easily seen scavenging for food (The Star, 2008c, p. N13; The Star, 2008d, pp. M10-11). This is posing serious threats to the users and the public. As a result of the filthy and unhygienic conditions of the markets, authorities at the Kuala Lumpur City Hall and Petaling Jaya City Hall in particular have been charged to take appropriate measures to mitigate the deplorable conditions of the market areas.

The Ministry of Housing and Local Government has received between 2,400 and 4,500 maintenance complaints each year over the last five years (Chuan, 2008). The spate of complaints centred on wall cracks, roof leakages, plumbing problems, poor plaster, painting, and ground settlement. This means that for the last five years they have received not less than 20,000 maintenance complaints. Arguably, many more were not reported or even documented, and also, these figures are just for one sector covering only the public 
property. Other ministries and government agencies will have a similar pool of maintenance complaints. The ministries of Health, Defence, Education, and Works have an extensive pool of buildings of various types and size under their care. Further, the large amounts of building stocks were owned by property developers. Private developers might not document their maintenance problems for public consumption if they do at all. They often consider such information as secret and not for public consumption. Research conducted to assess the level of satisfaction with the condition of low-cost buildings in Kuala Lumpur revealed that the users were not satisfied with the maintenance factor in their buildings (Hamzah et al., 1999). A survey of some public toilets in public parks, cinemas, eateries, shops, markets, and petrol stations found that most of the toilets were not hygienic (New Straits Times, 2008). Research has further suggested that many buildings lack adequate maintenance in Malaysia (Mohd Zulakhmar, 2006; Zainal Abidin and Roslan, 2006). Thirty families have been reported to be living in flats with serious structural problems that were hazardous for residents in Klang Valley (The Star, 2008e, p. M6) As a result of the persistent maintenance problems facing public buildings in Malaysia, the prime minister has set up a high-level team to investigate 72 government buildings in Putrajaya, 22 in Kuala Lumpur, and 168 rented offices (The Star, 2007, p. N14).

According to the Prime Minister of Malaysia, Dato' Seri Abdullah Ahmad Badawi, Malaysia is losing billions of ringgit due to the poor maintenance of public buildings and amenities (The Star, 20th February, 2006). Five hundred and ten heritage buildings have been declared eyesores and dangerous to the users and the public in George Town, Penang (New Straits Times, 2008, p. 20). In an effort to improve the conditions of the buildings, the State Government has concluded on the arrangement to provide the sum US\$60m as soft loans to the buildings owners. The above analysis, therefore, illustrates that there is a huge backlog of building maintenance in Malaysia even though expenditure on maintenance is on the increase. Certainly, the maintenance backlog will continue to increase, as buildings require maintenance to be functional. Buildings require effective maintenance, otherwise they become a burden to clients, users, and the general public. Maintenance cannot be circumvented, but can be maximised proactively. Therefore, due to the backlog of several years of building maintenance, there is an urgent need to improve the ways building maintenance management is executed in Malaysia. Otherwise, an extensive increase in investment is likely to be needed in the very near future to rectify defect, decay, and deterioration, which will, by then, be much more serious. This is coupled with the depressed level of current spending on building maintenance and the neglect of some of the works that require maintenance. The 0.5 per cent allocation of the development expenditure to the sector is grossly inadequate to cater for the backlog. This becomes even more imperative in order to meet one of the strategic thrusts of providing adequate, affordable, and quality houses, with greater prominence given to a conducive environment in consonance with one of the requirements of the Malaysian Vision 2020 as reiterated under the Ninth Malaysian Plan (Government of Malaysia, 2006).

\section{ASSESSMENT OF MAINTENANCE MANAGEMENT PROCEDURES}

The growing significance of building maintenance has also generated an increasing interest in developing maintenance management procedures to improve the performance of buildings in Malaysia. As an illustration, it was concluded that the fundamental problem is ineffective maintenance management (Ahmad, 2006). Mohd Nizar (1998) also observed that there is a need to review, revaluate, and reassess maintenance policies with serious consideration for safety and security criteria. Kayan (2006a, b) outlined that there 
is a need for proper maintenance management in order to minimise building maintenance. Zailan (2001) outlined that maintenance management in Malaysia is not conclusive, as it does not take risk factors into account while formulating maintenance policy. Based on the outcome of the research conducted by Syamilah (2006), more than 90 per cent of the respondents concurred that there is a need for further improvement (which should be broader) in the practice of the maintenance management procedure of buildings in Malaysia. Syamilah (2006) further asserted that the dominant maintenance practices are reactive and condition based. Ahmad et al. (2006) asserted that a fundamental problem with building maintenance problems in Malaysia is the lack of sufficient attention to the maintenance factor. Ignoring or not paying sufficient attention to the maintenance factor of a building will result in a building that will be expensive to own, since more than 50 per cent of the costs of ownership is attributable to maintenance (Seeley, 1987). Research further suggests that, due to poor maintenance policies, buildings in Malaysia are performing below users' expectations (Rozita, 2006). Also, it has been established that there is a gross inadequacy in the way in which the maintenance of schools' buildings is managed (Zainal Abidin and Roslan, 2006). Mohd Zulakhmar (2006) also asserted that the procedures of maintaining buildings in Malaysia are not effective and, in most cases, procedures are reactive in nature.

Based on a study determining the problems faced by property managers in managing high-rise condominiums in Malaysia, it was concluded that the most frequent complaints lodged by the tenants were defects not being attended to within the time specified, poor workmanship, and services and facilities not being in good condition even when taking over the building from the developers (Noraziah, 2006). In the conclusion of her study, Noraziah (2006) proposed a review of the current processes and procedures of handling defects in buildings in Malaysia. Mohd Zulakhmar (2006) concurred that maintenance practices in Malaysia are reactive and condition based. Tapsir et al. (2005) noted that with the multi-million ringgit invested to provide multi-storey housing projects in Malaysia, the maintenance factors were not properly managed.

Researchers at the University Technology Malaysia, in collaboration with the Ministry of Housing and Local Government, worked to develop the Life Cycle Cost for MultiStorey Housing (LICCOMS) (Tapsir et al., 2005). The model was able to estimate the lifecycle cost of a building as well as predict its service life. A major setback of the model is, however, the daunting amount of data it required to estimate lifecycle cost. In addition, future costs are very difficult to estimate, especially for maintenance work (Sherwin, 2000; Vanier, 2001). The application of the model can be very expensive, particularly for private building owners or users. Further, the model is a software tool, whereas the focus of this research is on hardware and, like the previous proposals, the LICCOMS is conditional based (Tapsir and Usman, 2004).

The above analyses suggest that the building maintenance management systems currently practised in Malaysia are piecemeal, operational, and hypothetical. There is no holistic link between the need for maintenance and the other clients' and users' value systems leading to reactive- and conditional-based maintenance policies. Maintenance is not considered a factor of production but rather a burden. In some cases, the authors tend to use complex and difficult computer programs and require data that are difficult to collect. It was, however, outlined that if organisations have formulated policies to correct a defective system and yet the deficiencies continue, the basic reason is probably ambiguities in the policies that need to be refined and improved (Sekaran, 2005). The deficiencies in the practices could be due to the way the policies are framed, how they are being understood or how they are enforced. Good maintenance management should be 
simple, dynamic, and capable of periodic review as the need arises to accommodate technological advancements and the clients' and users' value systems (Vanier, 2001; Jones and Sharp, 2007). When developing a maintenance management system, users (and client-occupiers) must be involved to ensure that their satisfaction is proactively taken into account while formulating the maintenance policy. In addition, the current proposals depend on the physical conditions of the building to establish the maintenance need and, therefore, are conditional based. Conditionally based maintenance is not a proactive maintenance policy. At best, all that a condition-based maintenance policy does is to provide a snapshot of the physical condition of the building at the specific time that the survey was conducted. According to Jones and Sharp (2007), a conditionally based maintenance policy is not explicitly linked to the ability of a building to support organisation performance. The physical condition of a building is just a symptom of defects, deterioration, or decay, or their combination. Under the current approaches to buildings maintenance, maintenance is not factored as a factor of production, which also leads to the fragmentation of the building management processes.

As a result of the inherent weaknesses in maintenance management in Malaysia, writers including Syamilah (2006), Zainal Abidin and Roslan (2006), Ahmad (2006), and Zailan (2001) have proposed alternative maintenance management models. The models were, however, still characterised by the same weaknesses inherent in the previous procedures. In fact, they were mostly hypothetical (Mohd Zulakhmar, 2006; Syamilah, 2006; Zainal Abidin and Roslan, 2006). Hypothetical recommendations are speculative adventures or imaginative preconceptions of the authors' thoughts that might be able to improve the performance of procedures, particularly considering the complexities associated with maintenance planning, control, and implementation. Corroborating this view, Cain (2004) outlined that assumptions could be counterproductive and, in fact, could negatively affect the long-term competitiveness of organisations.

Thus, it is apparent that a new system that puts the client-occupiers and users at the centre of maintenance management in order to preserve and enhance the value of the buildings and to enable a building to perform efficiently and effectively needs to be formulated. What is required is a system that will underpin the nature, practice, and kind of the required building maintenance. Building maintenance management should be extended beyond the current condition, based on the availability of funds. There should be comprehensive and systematic procedures for examining the building while paying considerable attention to the building's age, previous maintenance records, and the users' satisfaction, perceptions, and conditions. Value-based maintenance management seeks to plan, control, coordinate, organise, and implement maintenance activities, focusing on the efficient allocation of resources in order to improve the value of a building without undermining the users' perceptions and expectations. On the other hand, it has to ensure the reliability, safety, availability, and quality of the building. A fundamental aim of building maintenance management is to enhance the productivity, satisfaction, and efficiency of activities taking place in and around the building. In other words, it is a proactive procedure that is used to achieve efficient maintenance activities in a building by minimising the expenditure and optimising the value derived. Building maintenance management ties an organisation's productivity and objectives to maintenance needs. Maintenance management that is based on value has the capacity to identify the maintenance needs as part of the production and operation strategy of an organisation. It also plans and controls maintenance works and sets priority criteria for the maintenance works. 


\section{CONCLUSION}

Buildings that require maintenance in Malaysia are many and, in fact, the list seems to be endless despite the huge amounts each successive government has invested in the sector. Therefore, there is a deficiency in the ways in which building's maintenance procedures are being managed. Various attempts have been made to improve the performance of buildings through maintenance. While such procedures offer the potential to improve the performance of maintenance management systems, the systems have, however, been reactive, hypothetical, and conditionally based. It is these substantial weaknesses in the proposed procedures that have created the fundamental problems with the existing and proposed building maintenance management procedure, causing their inability to improve the existing systems. Maintenance cannot be circumvented, but what is possible is that expenditure on building maintenance can be optimised through a proactive maintenance management system based on the concept of value. Users measure the performance of their building in terms of various criteria that are consistent with their value systems. Maintenance management procedures must be based on the user's value systems. A significant impetus of value-based maintenance management is the progressive realisation that maintenance must be viewed from engineering, scientific, technological, political, and commercial perspectives.

Note: The author converted the US\$ from the ringgit (RM) via Yahoo Currency Converter on 29th July, 2008 at an exchange rate of RM0.3067 to 1 US\$.

\section{References}

Ahmad, R.B.H. (2006) Maintenance Management and Services (Case Study: PERKESO, Buildings in Peninsular of Malaysia), Unpublished Master's Thesis, University Technology Malaysia.

Ahmad, R., Nur Azfahani, A. and Nur Haniza, I. (2006) 'The effects of design on the maintenance of public housing buildings in Malaysia - part one', Journal of Building Engineers, 30-33, available at http://www.abe.org.uk/abeinternational/int articles/Apr_06_The_effects_of_design_on_the_maintenance_of_public_housing_Part_1.pdf.

Cain, C.T. (2004) Performance Measurement for Construction Profitability, Blackwell Publishing, Oxford.

Central Bank of Malaysia. (2006) Central Bank of Malaysia Annual Report, Central Bank of Malaysia, Kuala Lumpur.

Chuan, O.K. (The Minister of Housing and Local Government) (2008) Call for check on buildings: architects push for inspection every five years, The Star, 9th May, 2008, p. N33.

Construction Industry Development Board. (2003) Malaysia (CIDB) Directory 3rd edn, Builder's Infornet (M) Sdn Bhd, Selangor.

Department of Statistics Malaysia. (2006) Malaysia Economic Statistics-Time Series, ISSN 0127-9181.

Government of Malaysia. (2006) Ninth Malaysian Plan 2006-2010, Economic Planning Unit Prime Minister's Department, Putrajaya.

Hamzah, A., Kwan, C.L. and Woods, P.C. (1999) 'Quality function deployment in construction design: application in low-cost housing design', International Journal of Quality and Reliability Management, 16(16), 591-605.

Hishamuddin, M.A. and Buang, A. (2006) 'Real estate education in Malaysia: a new paradigm', in Proceedings of International Real Estate Research Symposium (IRERS) 2006, 11-13th April, 2006, PWTC Kuala Lumpur, Malaysia.

Jones, K. and Sharp, M. (2007) 'A new performance based process model for built asset maintenance', Facilities, 25(13/14), 525-535.

Kayan, B. (2006a) 'Maintaining old building during post gazzeted period — case study: Kuala Lumpur, the Malaysian surveyor', The Journal of the Institution of Surveyors, Malaysia, 15-22, ISSN 0127-4937PP735/2/2006.

Kayan, B. (2006b) 'Building façade defects analysis in old British colonial building conservation in Kuala Lumpur', in Proceedings of the Annual Management in Construction Researchers Association Malaysia (MICRA, 2006), Kuala Lumpur.

Mohd Nizar, B.J. (1998) 'Reducing costs through a predictive and preventive maintenance plan during the economic downturn', Journal of Building Property Review, 14(7), 8-9.

Mohd Sidek, H. (2007) (Chief Secretary to the Government of Malaysia) 'National Asset and Facilities Management Development', Special Key Note Address delivered at the National Asset and Facilities Management (NAFAM) Convention, Kuala Lumpur, Malaysia. 
Mohd Zulakhmar, B.Z. (2006) Strategic Planning in Maintaining Sports Facilities in Malaysia in Teluk Danga International Games Convention, Johor, Malaysia.

New Straits Times. (2007) Cracks show up on Jalan Duta Court Complex wall, 4th May, p. 14

New Straits Times. (2008) 40 Scramble to safety as cornice comes crashing down, 24th July, p. 12.

New Straits Times. (2008) 510 Heritages Building Need Help, 5th August.

New Straits Times. (2008) 'Downright filthy business', 19th June, p. 5.

Noraziah, A.A.A. (2006) The Study of Problems Faced by Property Management in High Rise Condominium in Malaysia, Unpublished Master's Thesis, University Technology Malaysia.

Rozita, B.A. (2006) Maintenance Factors in Building Designs, Unpublished Master's Thesis, University Technology Malaysia. Seeley, I.H. (1987) Building Maintenance, 2nd edn, Macmillan Press Limited, London.

Sekaran, U. (2003, 2004, 2005) Research Methods for Business: A Skill Building Approach, 4th edn, John Wiley and Sons, Inc, USA.

Sherwin, D. (2000) 'A review of overall models for maintenance management', Journal of Quality Maintenance Engineering, 6(3), 138-164.

Syamilah, B.Y. (2006) Maintenance Management through Strategic Planning for Public School in Malaysia, Unpublished Master's Thesis, University Technology Malaysia.

Tan, C.Y. (2006) A Handbook for Improving Real Estate Project Delivery in Malaysia: Analysis Comparison and Selecting the Best Method, Unpublished Master's Thesis, MIT Libraries, Massachusetts Institute of Technology.

Tapsir, S.H. and Usman, F. (2004) 'Service Life Planning for Affordable Housing Design — A Challenge to Malaysian Construction Industry, Design Life of Buildings and Constructed Assets', SIRIM Berhad, Shah Alam, March 2004.

Tapsir, S.H., Yatim, J.M. and Usman, F. (2005) 'Toward better housing management: service life planning in achieving sustainability for affordable housing?', in The Tenth International Conference on Civil, Structural and Environmental Engineering Computing, Rome, Italy, 31st August-3rd September, 2005.

The Europa World Year Book. (2004) Malaysia: Introductory Survey, Vol. 11, 45th edn, Taylor \& Francis (Europa Publications) Group, London, pp. 2756-2791.

The Europa World Year Book. (2005) Malaysia: Introductory Survey, Vol. 11, 46th edn, Taylor \& Francis (Routledge) Group, London, pp. 2817-2853.

The Europa World Year Book. (2006) Malaysia: Introductory Survey, Vol. 11, 47th edn, Taylor \& Francis (Routledge) Group, London, pp. 2852-2889.

The Europa World Year Book. (2007) Malaysia: Introductory Survey, Vol. 11, 48th edn, Taylor \& Francis (Routledge) Group, London, pp. 2932-2969.

The Star. (2006) Billions wasted to Repairs, Buildings and Amenities, 20th February.

The Star. (2007) Immigration Headquarters Havoc: leak on the seventh floor sends water down five levels, 12th April, p. N4.

The Star. (2008a) Ambrin promises thorough check: inspection team to check 94 public buildings, 4th June, p. N14.

The Star. (2008b) Cornice crash at main lobby: human error blamed for incident, 24th July, p. N14.

The Star. (2008c) Revolving scene at filthy market: entrails and rotting carcass left in the open, 28th July, p. N13.

The Star. (2008d) Situation unchanged: follow up visit shows little improvement, 11th August, pp. M10-11.

The Star. (2008e) A disaster just waiting to happen: 30 families living in flats with big cracks on the walls, 8th May, p. M6.

United Nations. (2006) National Account Statistics: Main Aggregates and Detailed Tables, 2005, Parts 11, Department Economics and Social Affairs, United Nations, UK.

Vanier, D.J. (2001) 'Why industry need asset management tools', Journal of Computing in the Civil Engineering, 15(1), 35-43.

Zailan, M.I. (2001) 'The management of public property in Malaysia', A paper presented in New Technology for New Century International Conference, Organised by FIG (International Federation of Surveyors) (Working Week, 2001) Seoul, Korea, available at http://www.fig.net/pub/proceedings/korea/full-papers/session29/mohd-isa.htm, accessed on 12th May, 2008.

Zainal Abidin, A.C. and Roslan, A. (2006) "Maintenance management process model for school buildings': an application of IDEF0 modeling methodology', in Utama, W.P. and Peli, M. (eds) International Conference on Construction Industry 2006, 21-24th June, 2006, Indonesia, Padang, pp. 81-87, available at www.fab.utm.my/ download/conference seminar.icci 200681pp12.pdf.

Zuhairuse, M., Ahmad, R., Adi-Irfan, C. and Norngainy, M. (n.d.) 'Correlational study between facilities management components of multi-ownership housing in Malaysia: a case study of Klang Valley', available at http://www.fab. utm.my/download/ConferenceSemiar/ICCI2006S1PP08.pdf, accessed on 12th March, 2008. 